\title{
A NANOTECNOLOGIA E A EXPLORAÇÃO DAS RIQUEZAS NACIONAIS A PARTIR DA CONTRIBUIÇÃO DA ANÁLISE ECONÔMICA ${ }^{1}$
}

\author{
Daniela Regina Pellin ${ }^{2}$ \\ Wilson Engelmann ${ }^{3}$
}

\begin{abstract}
Resumo
A Constituição Federal de 1988, no artigo 170, dispõe que as empresas privadas compõem a ordem econômica do país e, portanto, são responsáveis, ao lado do Estado neoliberal que é o Brasil, pela produção de riqueza nacional e o avanço social e econômico da população. Também é corolário constitucional que esse desenvolvimento econômico esbarra em contornos sociais, jurídicos e econômicos que garantam aos cidadãos brasileiros sua dignidade. Em se tratando de exploração nanotecnológica observa-se que esses ditames não vêm sendo cumpridos pelo Estado que permite, e pelas empresas que colocam em circulação, bens de toda ordem manufaturados a partir de nanotecnologia, sem a segurança social necessária diante de inúmeras vantagens econômicas. Constata-se, portanto, que há uma operação matemática de custos, perdas e lucros, cujos fatores estão em desajuste com a pretensão do legislador constituinte. Por que se adota essa política governamental e corporativa no Brasil? Qual seria o cálculo perfeito para atender ao equilíbrio pretendido pelo legislador constituinte? Essas perguntas percorrerão a pesquisa que não tem o condão de esgotar o tema; mas, ao final, provavelmente, constatar-se-á que a análise econômica do Direito da Escola de Chicago e que já vem sendo reconhecida pelo Sistema Judiciário nacional pode auxiliar o Brasil na construção de solução para o dilema segurança versus lucro, justamente, para percorrer o desafio de construir uma sociedade justa e igualitária, fins políticos colimados na Carta Constitucional.
\end{abstract}

Palavras-Chave: Desenvolvimento sócio-econômico. Nanotecnologia. Riscos. Análise Econômica do Direito. Equilíbrio.

\section{INTRODUÇÃO}

\footnotetext{
${ }^{1}$ Resultado parcial da investigação desenvolvida pelos autores no âmbito do seguinte projeto de pesquisa: "Observatório dos Impactos Jurídicos das Nanotecnologias: em busca de elementos essenciais para o desenvolvimento do diálogo entre as Fontes do Direito a partir de indicadores de regulação às pesquisas e produção industrial com base na nano escala": Edital Universal 14/2014 - CNPq.

${ }^{2}$ Doutoranda em Direito Público na UNISINOS. Professora de Graduação em DIreito na UNINOVE/SP; Pesquisadora em IC PIC - PIBIC e orientadora em Trabalhos de Conclusao de Curso em Direito na UNINOVE/SP. E-mail: daniela.pellin@terra.com.br

${ }^{3}$ Doutor em Direito pela Universidade do Vale do Rio dos Sinos - UNISINOS. Professor da Universidade do Vale do Rio dos Sinos - UNISINOS. Coordenador Executivo do Mestrado Profissional em Direito da Empresa e dos Negócios da UNISINOS. Coordenador Adjunto do Programa de Pós-Graduação em Direito - Mestrado e Doutorado - da UNISINOS. Líder do Grupo de Pesquisa JUSNANO (CNPq/Unisinos).E-mail: wengelmann@unisinos.br
} 
A Constituição da República de 1988, estabeleceu um divisor de águas na história social, econômica, política e jurídica do país, eis que é sabido que os legisladores constituintes nacionais optaram, na mesma ordem, pela construção de uma sociedade justa e igualitária, neoliberal e democrática e com um sistema de garantias individuais e fundamentais que, reunidos, subsumem a dignidade; tudo a promover o crescimento do país e das pessoas.

Contudo, passados os anos, desde então, verifica-se um descompasso entre as pretensões constitucionais e a sua efetividade, cujo resultado é flagrantemente visto pelo exacerbado enriquecimento de poucos, não obstante, o aumento das desigualdades sociais, da depauperação cultural e educacional, da pobreza, da marginalização, da ausência de investimentos em infraestrutura.

Também, insere-se neste contexto, no qual o Brasil é parte integrante, o sistema da globalização econômica e tecnológica, a partir dos idos de 1990, que constituiu verdadeira alavancagem econômica de empresas transnacionais que não deixaram e não deixam suas riquezas no país, mas, aqui, exercem atividade econômica. Aproveitam-se, sobretudo, da mão-de-obra barata dos residentes, sugam as riquezas naturais e alteram a política, a economia, os comportamentos sociais, a educação e a cultura interna, reduzindo o Estado à época da colonização de exploração, sem prejuízo da intervenção direta de organismos internacionais alterando o curso da história nacional, mitigando a soberania.

Neste cenário, o desenvolvimento nanotecnológico é elemento componente e figura como panaceia de mudança para um Brasil melhor, pois, o país está inserido nesse desenvolvimento. Muito embora, as empresas nacionais e transnacionais, pequenas, médias e grandes, venham explorando a atividade econômica com base em tais avanços tecnológicos, fato é que essa atividade, deveras lucrativa, coloca em risco os cidadãos porque não há comprovação científica sobre a segurança dos processos envolvidos por ela.

Assim, no exercício da livre iniciativa sem qualquer controle, é que se observa que as empresas têm investido, ao lado do Governo, em pesquisas para a expansão, cuja finalidade é a competição internacional e o achatamento dos custos nas operações econômicas, cujo destinatário final, é o cidadão e o mercado. O Governo, através do Poder Executivo, também, tem feito sua parte como maior investidor em pesquisas para estimular o desenvolvimento.

Verifica-se que, no caso da nanotecnologia, a ciência econômica da maximização do lucro vem sendo aplicada, de forma a ignorar os riscos ao homem e ao ecossistema porque o Brasil faz parte do rol de países identificados como sendo de modernidade tardia, onde o risco assumido é elementar da corrida desenvolvimentista.

Portanto, a pesquisa tem como objetivo geral delimitar o contexto econômico e jurídico envolvendo nanotecnologia, desenhando cada ator e o papel que exerce nesse cenário. A partir desse recorte epistemológico, 
propor pontos de contato entre as respectivas ciências e os interesses desses atores, cujo objetivo, ao final, é apresentar possíveis soluções para esse diálogo acontecer de forma democrática e horizontalizada e promover a efetividade das garantias constitucionais que afetam a todos os envolvidos.

Para tal enfrentamento, sobretudo, para auxiliar na construção de alguma solução econômica com força jurídica, é possível adotar-se estudos sobre a Análise Econômica do Direito, a partir dos pensamentos de Richard Posner. A partir daí se pretende avançar, na teoria proposta, já que, tratada na seara da discricionariedade judicial aplicada em demandas judiciais, precisa alavancar-se para o ambiente corporativo extrajudicial e orientar, mediante escolhas racionais pela retomada da ética da responsabilidade e construção deontológica de uma gestão corporativa voltada para esse fim: a maximização da riqueza, cujo conceito é corolário de justiça de mercado social e do homem.

\section{A NANOTECNOLOGIA, A ECONOMIA E A SOCIEDADE BRASILEIRA}

As implicações nanotecnológicas são de grande envergadura, pois, uma vez aplicadas em todo tipo de produtos manufaturados e destinados ao Homem, não tem experiências científicas suficientemente seguras de que em contato com o corpo ou com o meio ambiente, suas propriedades não sejam alteradas e disso decorra intoxicação que desencadeie doenças, mortes, lesões físicas, psíquicas e destruição do meio ambiente em toda sua completude. E não é só! As nanotecnologias com características de nanorobôs podem adquirir vida própria.

A nanotecnologia desenvolve alterações moleculares que, por sua vez, alteram outras moléculas que, no seu agrupamento, modificam as características de produtos, podendo ser considerada como um valor agregado ao produto. Trata-se de manipulação atômica e molecular em escala do nanômetro, ou seja, em escala de bilionésimo de metro, sendo desenvolvida nos últimos vinte anos, alcançando áreas como biotecnologia, materiais e instrumentação. Não há como saber exatamente a quantidade de produtos já disponíveis no mercado para consumo, mas, sabido é que promove melhores resultados e eficiência com menor custo ${ }^{4}$.

É possível afirmar que, mesmo havendo informação no rótulo dos produtos, provavelmente o cidadão não tem condições de identificar se a base do produto foi alterada por nanotecnologia, pois, a mesma constará no rol de propriedades químicas, cuja nomenclatura é técnica, não compreendida pelos cidadãos.

\footnotetext{
${ }^{4}$ Segundo estudo desenvolvido por Helmuth Kayser Consultancy, em 2001 haviam 300 produtos desenvolvidos a partir das nanotecnologias no mercado global e, em 2009, mais de 2500, espera-se um crescimento de $25 \%$ ao ano. Um novo estudo está em andamento, buscando inventariar o número atual de produtos à base da nano escala. Disponível em: <http://www.hkc22.com/nanobasedproducts.html> Acesso em 30 jul. 2015. Estes dados quantitativos divergem daqueles existentes na página do PEN - The Project on Emerging Nanotechnology, que mostra números bem menores de produtos com nanotecnologia no mercado: estariam disponíveis mais de 1.600 produtos de consumo identificados pelo fabricante com base em nanotecnologia introduzidos no mercado. Disponível em: http://www.nanotechproject.org/ Acesso em: 30 jul. 2015. A divergência encontrada pelos autores deste artigo, mostra a dificuldade de se ter um cenário mais ou menos próximo da realidade.
} vol.09, no. 01, Rio de Janeiro, 2016.pp. 460-484 
Não obstante, a nanotecnologia seja desenvolvida e implantada em bens e serviços com o objetivo de favorecer o Homem e sua qualidade de vida, esbarra nos avanços econômicos e no acúmulo de capital. Hoje, praticamente, todos os setores produtivos já sofrem a interferência das nanotecnologias, tal como apontado pelo infográfico abaixo.

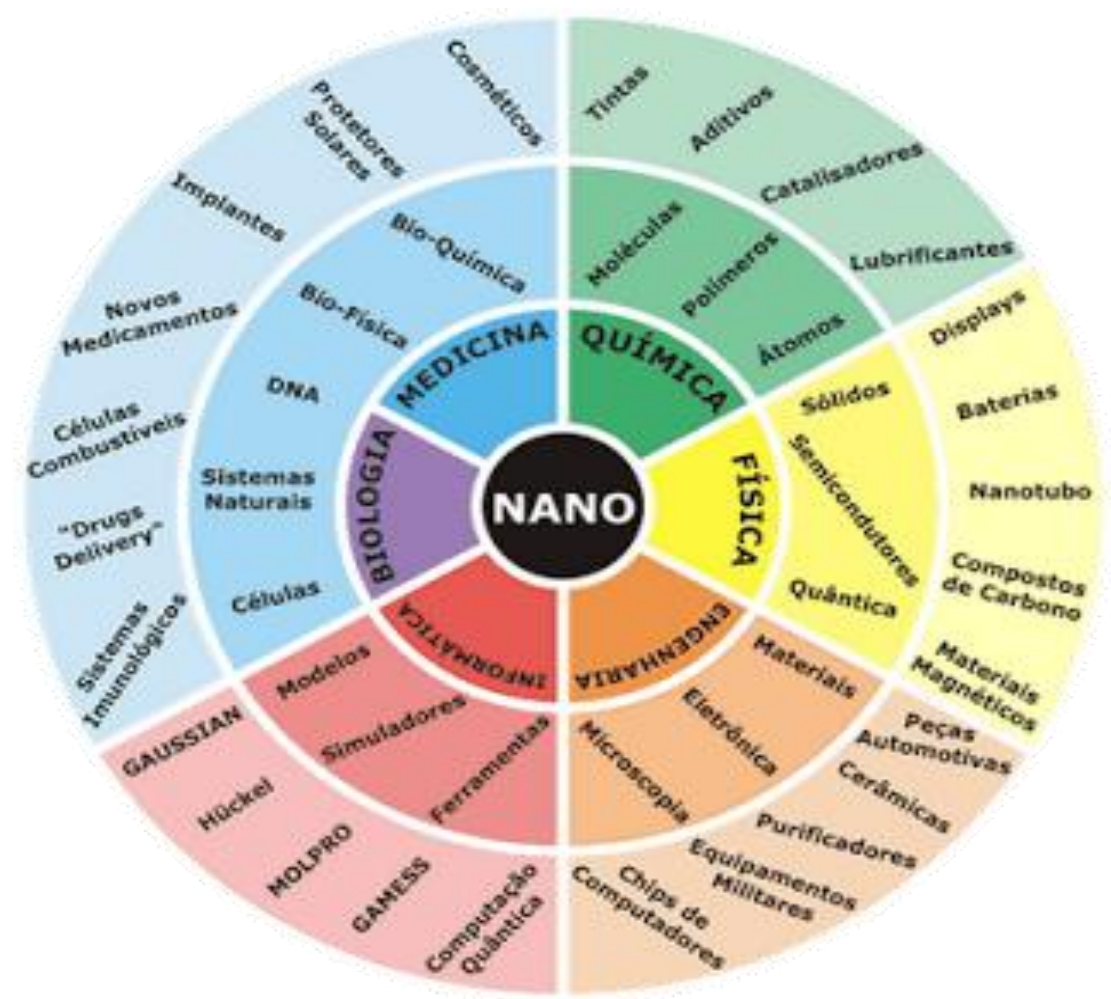

Fonte: www.google.com.br/search, acessado em 30 de julho de 2015.

Pelo quadro abaixo, também, é possível ter-se noção de alguns produtos que são postos no mercado de consumo, correspondendo a algumas das áreas do infográfico acima: 


\begin{tabular}{|c|c|}
\hline Setor & Tipo de Produto/Observaçôes \\
\hline Energia & $\begin{array}{l}\text { Sistemas fotovoltaicos; celulas solares; grids } \\
\text { de energia; baterias; pás para geradores } \\
\text { eólicos. }\end{array}$ \\
\hline lluminação & $\begin{array}{l}\text { LEDs baseados em quantum dots para ilumi- } \\
\text { nação pública, domiciliar e automobilistica. }\end{array}$ \\
\hline Automobilistico & $\begin{array}{l}\text { Pinturas especiais (não riscam, autolimpan- } \\
\text { tes): catalisadores para conversores catalíti- } \\
\text { cos para gases de escapamento; eletrônica } \\
\text { embarcada; tecidos antibacterianos. }\end{array}$ \\
\hline Esportes & $\begin{array}{l}\text { Raquetes de tênis (nanotubos de carbono); } \\
\text { roupas esportivas antitranspirantes e antibac- } \\
\text { tericidas; calçados para esportes; quadros } \\
\text { para bicicletas; tacos de golf; luvas para } \\
\text { esportes. }\end{array}$ \\
\hline Tecidos & $\begin{array}{l}\text { Tecidos resistentes a sujidades (efeito lótus); } \\
\text { tecidos antibactericidas; tecidos técnicos e } \\
\text { não tecidos. }\end{array}$ \\
\hline Embalagens & $\begin{array}{l}\text { Embalagens com propriedades de barreira } \\
\text { (umidade, gases), a base de nanocompósitos; } \\
\text { embalagens inteligentes, sensiveis a gases } \\
\text { de decomposição de alimentos; recipientes } \\
\text { bactericidas (prata) para guardar alimentos } \\
\text { pereciveis. }\end{array}$ \\
\hline Cosméticos & $\begin{array}{l}\text { Protetores solares; produtos para recupe- } \\
\text { ração da pele; produtos contendo cores } \\
\text { físicas (indice de refração): produtos } \\
\text { para maquiagem. }\end{array}$ \\
\hline Fármacos & $\begin{array}{l}\text { Novas formas de administração de fármacos } \\
\text { (nanoemulsões e nanopartículas): drug-deli- } \\
\text { very; terapia de cânceres. }\end{array}$ \\
\hline
\end{tabular}

Fonte: www.google.com.br/search, acessado em 30 de julho de 2015.

A Agência Brasileira de Desenvolvimento Industrial (ABDI), em documento elaborado no ano de 2010, denominado "Panorama Nanotecnologia", informou que o Brasil ocupa a $25^{\circ}$ posição no ranking da Science Metrixem pesquisas nanotecnológicas, com bastante energia e investimentos gastos nos últimos anos e, em franca expansão, especialmente nos setores farmacêuticos, químicos, cosméticos e agroindustrial.

Em março de 2015, Brasil e Estados Unidos assinaram convênio para o desenvolvimento de tecnologias para energias renováveis e sustentáveis por meio de investimentos em nanotecnologia e capacitação em pesquisa de ponta no país.

A nanociência e a nanotecnologia $(\mathrm{N} \& \mathrm{~N})^{6}$ tem sido objeto de interesse em setores industriais e acadêmicos, devido aos benefícios na corrida tecnológica global e emancipação econômica que viabilize o resgate de sua soberania.

\footnotetext{
${ }_{5}^{5}$ AGÊNCIA BRASILEIRA DE DESENVOLVIMENTO INDUSTRIAL. Panorama nanotecnologia. Série Cadernos da indústria ABDI XIX. Brasília: ABDI, 2010, p. 32.

${ }^{6}$ Aplicações tecnológicas dos conhecimentos produzidos pela Nanociência, que representa os estudos dos nanomateriais, que são produzidos na nanoescala e/ou aqueles que contêm nano-objetos. Para ser considerado nanotecnológico, um produto deve atender a pelo menos uma das duas premissas:

1.Conter materiais em nanoescala com tamanho de partícula controlado, geral, mas não exclusivamente, abaixo de 100nm em uma ou mais dimensões, e

2.Proporcionar produtos melhores, que explorem as novas propriedades, que diferem daquelas dos átomos, moléculas e materiais macroscópicos. (GUTERRES, Silvia Stanisçuaski; BECK, Ruy Carlos Ruver; POHLMANN, Adriana Raffin. Nanocosmecêuticos. IN: COSTA, Adilson (Org.). Tratado Internacional de Cosmecêuticos. Rio de Janeiro: Guanabara Koogan, 2012, p. 428).
} 
Segundo a Folha de São Paulo ${ }^{7}$ de 25/05/2015, pequenas empresas nacionais estão trabalhando com nanotecnologia por ser um mercado muito rentável e o faturamento exponencial. Profissionais que saem da academia com estudos em mestrado e doutorado, também, estão passando a ser empresários do conhecimento adquirido, ou seja, do ativo intelectual.

O documento da agência salienta que o mercado é deveras promissor e muitas empresas têm interesse econômico em inserir a nanotecnologia em sua atividade econômica por causa da economia nos custos da produção, salientando que em 2014, o patamar de investimentos remontou a US\$ 2,6 trilhões, representando $15 \%$ da produção global de bens manufaturados ${ }^{8}$.

Contudo, muito embora já utilizada, consumida e descartada, fato é que não se sabe quais os riscos dessa interação entre partículas nano e partículas naturais diante da ausência de investigação científica que mensure os malefícios, presentes e futuros. A corrida pela implementação é maior do que a verificação dos resultados.

A própria Agência Brasileira de Desenvolvimento Industrial (ABDI) em parceria com a UNICAMP (Universidade de Campinas) elaborou documento, em 2011, destinado aos industriários nacionais que tem investido na inovação: "NANOTECNOLOGIAS: subsídios para a problemática dos riscos e regulação".

Trata o documento de uma cartilha de orientações ao desenvolvimento e aplicação nanotecnológica e, resumidamente, menciona quanto à problemática dos riscos, a necessidade de campanhas educativas do público acerca da percepção sobre nanotecnologia quanto aos beneficios e riscos; e, quanto à regulação, menciona que há necessidade dos agentes envolvidos orientar os legisladores participando ativamente da regulamentação, sobretudo, agir de forma segura a evitar os infortúnios dentro dos estabelecimentos com os atores envolvidos diretamente, mediante boas práticas de governança e ética no exercício da atividade.

Esse é o estado das artes da política, da economia e social do presente século para alguns países de modernidade tardia, como o Brasil. Ulrich Beck definiu que a sociedade de risco é a característica desses países, pois, aceitam um universo de incertezas com o fito da corrida para vencer o atraso:

Na modernidade tardia, produção social de riquezas é acompanhada sistematicamente pela produção social de riscos. Consequentemente, aos problemas e conflitos distributivos da sociedade da escassez sobrepõem-se os problemas e conflitos surgidos a partir da produção, definição e distribuição de riscos científico-tecnologicamente produzidos ${ }^{10}$.

Anthony Giddens, também, enfrentou a temática da modernidade tardia e os riscos advindos com a corrida descompassada, explicitando que os riscos são infortúnios projetados para o futuro e subestimados no

\footnotetext{
${ }^{7}$ Disponível em: <http://wwwl.folha.uol.com.br/mercado/2015/05/1632954-cientistas-abrem-pequenas-empresas-investindoem-nanotecnologia.shtml> acessado em 24 jul. 2015.

${ }^{8}$ Disponível em: <http://wwwl.folha.uol.com.br/mercado/2015/05/1632954-cientistas-abrem-pequenas-empresas-investindoem-nanotecnologia.shtml> acessado em 24 jul. 2015.p. 30.

${ }^{9}$ Disponível em: <http://www.abdi.com.br/Estudo/Relat\%C3\%B3rio\%20Nano-Riscos_FINALreduzido.pdf>. Acessado em 24 jul. 2015.

${ }^{10}$ BECK, Ulrich. Sociedade de risco - Rumo a uma outra modernidade. Tradução de Sebastião Nascimento. 2. ed. São Paulo: Editora 34, 2011, p. 23.
} 
presente. Assim, é possível compreender pelo cenário que se apresenta que tais infortúnios não interessam e são ignorados pelas decisões tomadas nessa corrida pela inovação tecnológica:

As culturas tradicionais não tinham um conceito de risco porque não precisavam disso. Risco não é o mesmo que infortúnio ou perigo. Risco se refere a infortúnios ativamente avaliados em relação a possibilidades futuras. A palavra só passa a ser amplamente utilizada em sociedades orientadas para o futuro - que veem o futuro precisamente como um território a ser conquistado ou colonizado. O conceito de risco pressupõe uma sociedade que tenta ativamente romper com seu passado - de fato, a característica primordial da civilização industrial moderna ${ }^{11}$.

É perceptível que o estado das coisas está nesse nível desde que o Homem, em nome de sua independência da natureza, acabou atropelando sua condição de parte integrante da mesma e passou a buscar sua redenção através do desenvolvimento exacerbado da técnica.

A técnica pela qual vive, sobrevive e respira o homem, é a forma encontrada para suprir o vazio que o assola; desde que desenvolveu sua capacidade de abstração de tudo o que pôde observar e elaborar a partir da natureza, subjugando-a; passou a desenvolver a técnica, a projetar suas angústias, alegrias e soluções. Umberto Galimberti, filósofo contemporâneo, conclama o homem ao retorno do pensamento crítico sobre a técnica, pois, só assim, será possível retomar as condições ideais para a tomada de decisões racionais e que agreguem valor ao humano, numa franca tentativa de reconstruir o universo interior do homem, perdido pelos exageros da técnica e que, hoje, se identifica como risco à própria espécie humana.

Reflete esse autor:

Nessa inserção rápida e inevitável, carregamos ainda dentro de nós os traços do homem prétecnológico, que agia em vista de objetivos inscritos num horizonte de sentido, com um estoque de ideias próprias e um conjunto de sentimentos nos quais se reconhecia. A idade da técnica aboliu esse cenário 'humanista', e as demandas de sentido continuam desatendidas, não porque a técnica não esteja ainda bastante aperfeiçoada, mas porque não se enquadra em seu programa encontrar respostas para semelhantes demandas ${ }^{12}$.

Todavia, constata-se que os riscos provocados com a exploração econômica e nanotecnológica tem reduzido o meio ambiente e o homem à condição de meios, faltando aos detentores do poder decisório a racionalidade filosófica que garanta a sobrevivência, equilíbrio e visão crítica, pois a técnica exacerbada restringe a ética e a moral, pois foi elevada à condição de fim em si mesma.

O próprio Galimberti, em artigo intitulado "O ser humano na idade da técnica” constata que:

A técnica, comumente considerada uma 'ferramenta' à disposição do homem, tornou-se, hoje, o verdadeiro 'sujeito' da história; o homem executa o papel de 'funcionário' de seus equipamentos, cumpre aquelas ações descritas e prescritas no rol de 'tarefas' das ferramentas e coloca sua personalidade entre parênteses em favor da funcionalidade ${ }^{13}$.

\footnotetext{
${ }^{11}$ GIDDENS, Anthony. Mundo em descontrole. O que a globalização está fazendo de nós. 6. ed. Rio de Janeiro: Record, 2007, p. 33.

${ }^{12}$ GALIMBERTI, Umberto. Psiche e Techne. O homem na idade da técnica. São Paulo: Paulus, 2006, p. 8-9.

${ }^{13}$ Disponível em: http://www.ihu.unisinos.br/images/stories/cadernos/ideias/218cadernosihuideias.pdf Acesso em 30 jul. 2015. vol.09, n. 01, Rio de Janeiro, 2016. pp. 460-484 
A nanotoxicologia é a ciência que vem colaborando com a pesquisa acerca de possíveis infortúnios que possam ser causados pela intoxicação e interação com as partículas nano, muito embora, os investimentos nesse tipo de pesquisas estejam muito aquém dos necessários para as certezas científicas que busca alcançar.

O quadro abaixo demonstra as áreas de investigação da nanotoxicologia que pode auxiliar na busca das certezas científicas almejadas.

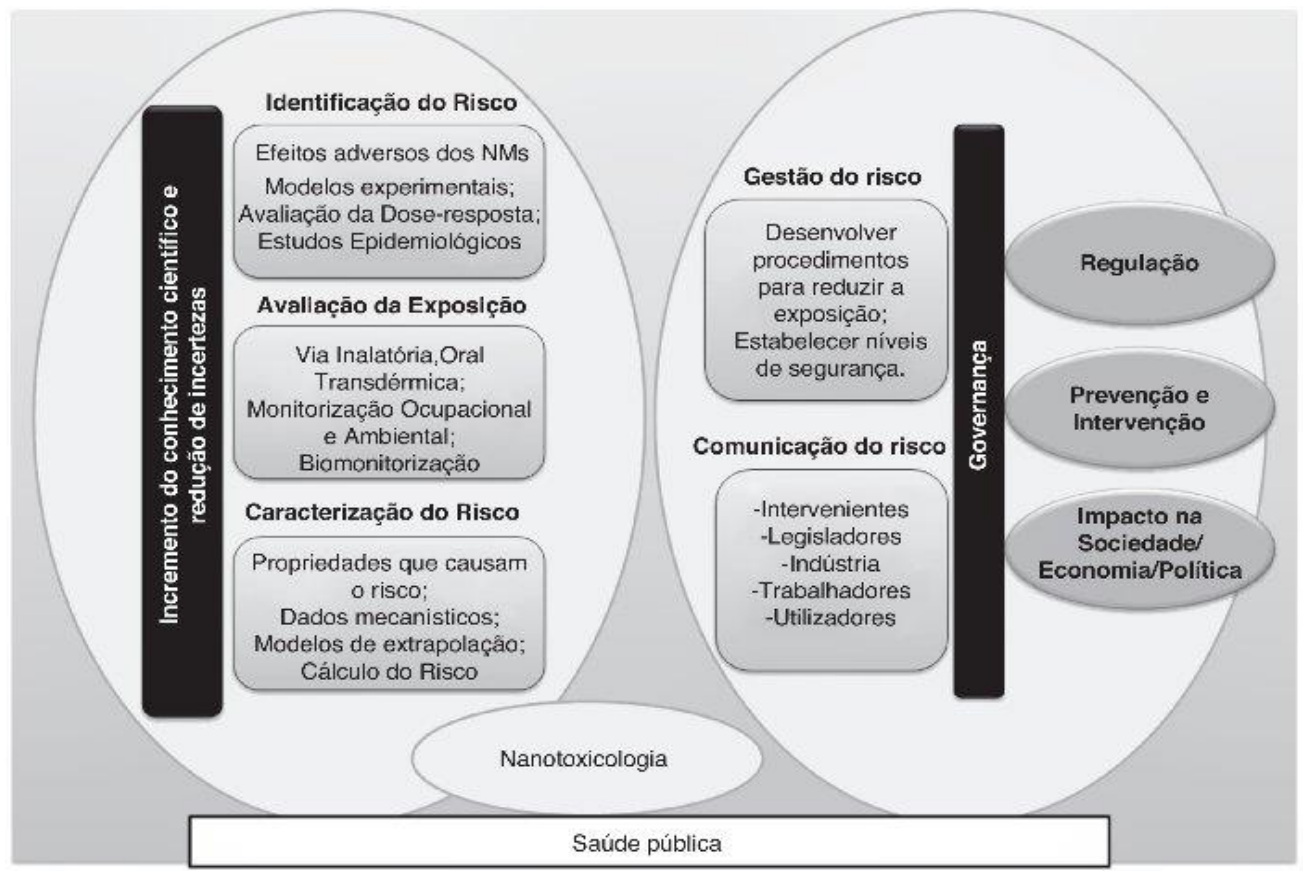

Fonte: <www.google.com.br/search> acessado em 30 jul. 2015.

Há, ao redor do mundo, iniciativas organizadas que vem se antecipando na divulgação de informações como precaução aos possíveis infortúnios nanotecnológicos, elencando uma lista de produtos manufaturados com a base nano e informando ao consumidor a respeito. O Danish Consumer Councile do Danish Ecological Council em cooperação com o Departamento do Meio Ambiente da Technical University Denmark (DTU), tiveram a iniciativa de, em 30 de janeiro de 2013, lançarem o databasenano (www.nano.taenk.dk). Uma iniciativa que catalogou mais de 1.200 itens elaborados com base nanotecnológica para consulta direta pelo consumidor, incluindo cosméticos, suplementos alimentares e outros itens. A intenção da parceria na criação do banco de dados é, justamente, informar o consumidor e deixar que ele exerça sua escolha consciente ${ }^{14}$.

Iniciativa igual está sendo tomada no Brasil, sob a coordenação do Professor da Universidade de São Paulo, Doutor Guilherme Frederico Bernardo Lenz e Silva ${ }^{15}$, ao criar em março de 2015, o site HSEnano Health, Safety, Enviroment (www.hsenano.com) com grande repositório informacional e de pesquisa a respeito

${ }^{14}$ Disponível em: <http://www.unochapeco.edu.br/quimica/noticias/lancado-banco-de-dados-com-informacoes-de-riscos-dananotecnologia-para-o-consumidor $>$. Acessado em 31 jul. 2015.

${ }^{15}$ Disponível

<file://C:/Users/daniela.pellin/Downloads/GUILHERME\%20LENS\%20PROGRAMA\%20100315\%20HSEnano\%20webpl atform\%202015\%20-\%20Renanosoma\%20(1).pdf>. Acessado em 25 jul. 2015. 
do que vem sendo desenvolvido pela cadeira da engenharia de materiais em nanotecnologia e nanotoxicologia, com apoio nacional do Governo Federal e de parecerias internacionais.

A Agência Brasileira de Desenvolvimento Industrial, nesse mesmo sentido, produziu o documento, com base em revisão de literatura, "Panorama Nanotecnologia" no afã de relatar os agentes econômicos os riscos nanotecnológicos que, além dos problemas já serem conhecidos aqui no Brasil, o assunto carece de marcos regulatórios e de conduta ética na exploração da atividade econômica nacional:

Marco regulatório, aspectos éticos e de aceitação pela sociedade ao lado do crescimento esperado de novos produtos e tecnologias baseados em N\&N, crescem, também, as preocupações sobre os riscos que elas podem provocar, particularmente aos trabalhadores, pela maior exposição a que são submetidos em seus ambientes operacionais. Os impactos nocivos e riscos potenciais à saúde humana e animal, ao meio ambiente e até em relação ao comportamento humano são ainda pouco conhecidos ${ }^{16}$.

Nesse contexto de incertezas e riscos e, sobretudo, ausência de controle estatal ou legislativo, resta aos próprios agentes econômicos o poder de decidir de forma racional acerca da exploração da inovação, enquanto as regulamentações estatais não vêm, ou suas propostas sejam adequadas a contento de salvaguardar ou reprimir infortúnios excessivos e perigosos.

As ciências econômicas apontam os cálculos a partir de suas bases; as ciências jurídicas - muito além do juspositivismo e em busca do Direito natural - apontam o fator humano, o meio ambiente e a sociedade como variantes da moral em qualquer operação econômica; já, a filosofia, retoma a ética, a política e a moral necessárias a todo desenvolvimento da humanidade.

\section{A ANÁLISE ECONÔMICA DO DIREITO E A ANÁLISE ECONÔMICA DA NANOTECNOLOGIA}

A construção jurídica que houve, no Brasil, para assimilar essas mudanças no cenário internacional com reflexos nacionais, veio com a Constituição da República de 1988. Mas, é a partir do artigo 170, que o Legislador incluiu as empresas na ordem econômica nacional, todavia, estabeleceu, a partir do exercício da livre iniciativa (artigo 170) e da concorrência de mercado, o fator humano como orientador de toda e qualquer atividade exploratória econômica, bem como, não menos importante, o meio ambiente e os pequenos empreendedores, justamente, na pretensão do equilíbrio social que, por certo, o futuro reclamaria:

Os direitos sociais, previstos a partir do artigo $6^{\circ}$ do Título II da Constituição federal de 1988, estão, em geral, relacionados a prestações a serem efetivadas pelo Estado, no que se refere à criação de um ambiente social de bem-estar, que ofereça aos cidadãos uma existência

${ }^{16}$ AGÊNCIA BRASILEIRA DE DESENVOLVIMENTO INDUSTRIAL. Panorama nanotecnologia. Série Cadernos da indústria ABDI XIX. Brasília: ABDI, 2010, p. 42. 
plena e digna, em consonância com os princípios e objetivos fundamentais da República, positivados no artigo $1^{\circ}$, incisos II, III e IV, e no artigo $3^{\circ}$, incisos I e IV, do Texto Maior ${ }^{17}$.

Nesse escopo, o Brasil assinou o Pacto Internacional do Livro Verde da Sociedade da Informação para a sua respectiva implantação em nosso território, no ano de $2000^{18}$.

Em 2002, com a reforma do Código Civil, veio para o ordenamento jurídico nacional, a teoria da empresa, doutrinada por Alberto Asquini, 1942, na Itália. O cientista jurídico constatou que a teoria dos atos de comércio (1804, França) evoluiu junto com as movimentações internacionais e, portanto, a atividade empresarial ganhou status de vida própria, independente do fator humano, pois, a partir de seus elementos estruturantes (visão poliédrica), a pessoa física (natural) descolou-se da pessoa jurídica (empresário e sociedade empresária) e, assim, as corporações passaram a avançar e a ditar as regras do jogo de mercado ${ }^{19}$ e a servir como ferramenta de mais acúmulo de capital, em detrimento da melhor distribuição de renda social.

Nesse cenário político, econômico e de desenvolvimento, se o Direito é chamado para atender às demandas sociais, é para reclamar a efetividade e o respeito aos direitos fundamentais, pois, o capital global aprimorou a exploração e desenvolveu técnicas hábeis a aumentar seu acúmulo de excedentes a custo das próprias pessoas como reflexo desse processo de crescimento global e o risco é um dos pilares desse processo de desumanização. Isso significa dizer que a pretensão constitucional vem perdendo soberania.

Até o momento séc. XXI, o que assistimos cotidianamente é o aumento das desigualdades, segundo Santos $\left(1996^{a}\right)$, renova as disparidades e cria novas desigualdades, o que é devido á violência dos seus processos fundadores, todos praticamente indiferentes às realidades locais. A aplicação brutal de princípios gerais a situações tão diversas é criadora de desordem ${ }^{20}$.

De outro lado, o Direito, também, não é suficiente para atender as demandas das empresas que reclamam por melhores políticas econômicas e jurídicas para melhor desempenho de suas atividades com segurança. E, nesse atrito identificado desde Karl Marx, quem fica excluído da operação entre ativos e passivos empresariais, são as pessoas, ora na figura de trabalhadores; ora, na figura de cidadãos ou consumidores, mas tendo como ator principal, apenas, o capitalismo representado pelo dinheiro, a mais valia.

Max Weber, a esse respeito, observou que "o ser humano em função do ganho como finalidade de vida, não mais o ganho em função do ser humano como meio destinado a satisfazer suas necessidades materiais" ${ }^{21}$, absorveu o capitalismo como sua ordem natural de vida. Mas, é em decorrência dos exageros causados com a

\footnotetext{
${ }^{17}$ CAMPOS, Juliana Cristine Diniz. Os direitos sociais como cláusulas pétreas na Constituição Federal de 1988. In MATIAS, João Luís Nogueira. (Coord.). Neoconstitucionalismo e Direitos Fundamentais. São Paulo: Atlas, 2009, p.189.

${ }^{18}$ Disponível em: <http://www.mct.gov.br/upd_blob/0004/4795.pdf>. Acessado em 26 jul. 2015.

${ }^{19}$ Nesse momento, o conceito de mercado deixou de ser troca entre vendedores e compradores para ser instituto auto governável das transações econômicas, sendo o dinheiro e o acúmulo de excedentes desse mesmo dinheiro, seu objeto de circulação.

20 CARVAlHO, Edmir de. Metropolização do Brasil e da América Latina, as máscaras atuais da desigualdade social. In CARVALHO, Edemir de. (Org.). Perspectivas da Globalização e das suas contradições no Brasil e na América Latina. São Paulo: LCTE, 2010, p. 248.

${ }^{21}$ WEBER, Max. A ética protestante e o espírito do capitalismo. São Paulo: Companhia das Letras, 2004, p. 46. vol.09, n. 01, Rio de Janeiro, 2016.pp. 460-484 
globalização econômica e a tecnologia mundial que os direitos e garantias individuais e fundamentais ganham a força necessária para envolver num só apelo: Direito Público, enquanto controle sobre a economia através da intervenção estatal no poder econômico; e, Direito Privado, comprometimento das empresas no desenvolvimento social, além da atividade lucrativa, almejando, com essa fusão, ditames de justiça social e econômica. Tudo isso, na reconstrução ou construção democrática da soberania constitucional.

Contudo, parece que esta operação entre o público e o privado não tem ponto de contato em se tratando de nanotecnologia, pois, as empresas entendem que a positivação - inclusive, sem a informação técnica necessária, como é o caso - vai emperrar a corrida desenvolvimentista; e, de outro lado, a sociedade entende que a positivação seria necessária para a mitigação dos riscos, pois, teme os infortúnios futuros ainda não mensurados, pois será deles vítima.

Neste momento da pesquisa, aqui no Brasil, há dois projetos de Lei em andamento, numa franca tentativa de unir as duas forças do mercado - público e privado, contudo, com críticas a serem lançadas à reflexão.

Um deles, Projeto de Lei no 5.133/13, pretende regulamentar a necessária rotulagem dos produtos destinados ao mercado, obrigando as empresas a inserir nos produtos a informação de que tais foram manufaturados com base em nanotecnologia.

Ocorre que, a mera informação não atinge a finalidade do projeto que é a de proteger o consumidor. É sabido que informação e conhecimento são institutos diferentes. Só o conhecimento absorve a informação. A informação não é capaz de gerar conhecimento acerca do objeto. Há necessidade de se educar esse consumidor, dando-lhe a conhecer sobre a informação rotulada, a fim de que possa exercer sua livre escolha consciente.

Portanto, falta ao projeto, a obrigatoriedade aos atores envolvidos promoverem campanhas educativas, dando a conhecer ao público em geral, do que se trata a nanotecnologia, seus benefícios e riscos e, assim, efetivando os ditames da política nacional de proteção ao consumidor, tal como discorre o artigo 4º da legislação consumerista.

A propósito, Wilson Engelmann, colaborando com a construção internacional dos preceitos envolvendo nanotecnologia, prelecionou nesse mesmo sentido no IAMOT 2015 (Internacional Association for Management of Technology), ocorrido entre 08 e 11 de junho passado, com os resultados da pesquisa The "compliance programs" as an alternative to business management to deal with the right to consumer information and with the risks brought by nanotechnology ao dispor que sem a educação dos consumidores, as tentativas de gerenciamento dos riscos não são ou serão suficientes:

The information should be accompanied by education. It is not enough to put a lot of information on the label or on the advertising of the product. It will be necessary to educate the consumer to read and interpret, know and understand its contents (ENGELMANN, CHERUTTI, 2013). The full exercise of the right to information, which belongs to the consumer, depends on a preliminary point: the practice of the information duty, which 
belongs to the manufacturer and marketer. So, there is a reciprocity and complementarity between rights and duties, which assume particular importance in the case of nanotechnology 22 .

Existe um mito em países onde imperam políticas públicas e privadas questionáveis de que educar e emancipar pode causar prejuízos econômicos e políticos em países de desenvolvimento tardio, quando, a bem da verdade, é justamente ao contrário. O cidadão educado e emancipado retoma o controle sobre as atividades pública e privada e passa a ser a pedra fundamental da sociedade, estimulando a concorrência e dando efetividade à soberania nacional pretendida pelo legislador constitucional.

O segundo, Projeto de Lei no 6.741/13, pretende dispor sobre a Política Nacional da Nanotecnologia, sua pesquisa, monitoramento, controle, produção, uso e o destino de seus resíduos.

Esse projeto dispõe sobre os princípios que devem nortear todo o desenvolvimento nanotecnológico e, lança sobre o Poder Público (União, Estados, Territórios e Municípios) o dever de efetivar tais princípios através da implementação da política nacional, cabendo à União, a coordenação.

Os princípios que devem nortear a política nacional são elencados no artigo $2^{\circ}$ : informação, transparência, participação social, precaução, prevenção e, sobretudo, a responsabilidade social.

No plano dessas políticas os agentes econômicos devem comercializar produtos observando o princípio da precaução, bem como, pressupor autorização sanitária e ambiental, mas não diz como isso será realizado, conforme se depreende do artigo $6^{\circ}$. Entende-se, portanto, que fica ao encargo moral das empresas a implementação de suas políticas de precaução. As demais regras que norteiam o Projeto tratam do controle estatal sobre a atividade nanotecnológica, formação de banco de dados, autorizações etc.

A crítica que se faz é que o projeto é incompleto e se preocupa com o controle estatal sobre o desenvolvimento, daí as duras críticas lançadas em plenário legislativo que, se aprovado sem reformas, emperrará, por inaptidão técnica da própria proposta, o andamento do desenvolvimento tecnológico.

Em Audiência Pública, realizada no dia 25 de junho de 2015, em reunião conjunta da Comissão de Meio Ambiente e Desenvolvimento Sustentável e a Comissão de Ciência e Tecnologia, Comunicação e Informática ficou bem clara a dicotomia existente entre os integrantes das Ciências Exatas e os integrantes das Ciências Sociais Aplicadas: aqueles não querem a regulação legislativa, criticando ambos os mencionados projetos de lei; estes, buscando a participação do Direito no cenário das discussões sobre as nanotecnologias, seus riscos, possibilidades e impactos sociais e ambientais. Além do mais, o setor empresarial fortemente influenciando os cientistas das Ciências Exatas, mostra um cenário preocupante em relação às nanotecnologias no Brasil. ${ }^{23}$

22 BOTHA, Anthon. Future Thinking and Managemente of Technology. IAMOT, 2015. Disponível em: http://www.iamot2015.com/documents/FutureThinkingAndMOT-IAMOT2015.pdfAcesso em 31 jul. 2015.

${ }_{23}$ Disponível em: < http://www2.camara.leg.br/camaranoticias/noticias/CIENCIA-E-TECNOLOGIA/491084REGULAMENTACAO-DE-PRODUTOS-COM-NANOTECNOLOGIA-DIVIDE-OPINIAO-DEPESQUISADORES.html> Acesso em 30 jul. 2015. 
Um bom projeto de lei acerca da política envolvendo nanotecnologia deveria, de forma participativa e democrática, ser implementado com regras dialógicas e sistematizadas, a fim de harmonizar o sistema e o desenvolvimento para o mercado, entendendo por mercado "um espaço público de interação social e coletiva, tendente a situações de equilíbrio", explica Luciano Benetti Timm. "Com efeito, o mercado existe como uma instituição social espontânea, vale dizer, como fato"24, continua.

Engelmann tem sido fortemente consultado a respeito de como legislar no Brasil o assunto nanotecnologia; tem participado, ativamente, das convocações para compartilhar suas pesquisas no Congresso Nacional e tem, sobretudo, repisado que a forma ideal de se legislar é a horizontal e democrática, pois, são muitos os atores envolvidos e muitos os reflexos, desejados e indesejados, já que a forma científica, econômica, social e política é globalizada, como se pode ver do trecho pinçado de uma de suas pesquisas recentemente compartilhadas no IAMOT 2015:

The introduced scene reveals the insufficiency of the text of law to manage information, both from the perspective of law, and by the side of duty, since it is about ethical, legal and social aspects. To the Law System, from the need to operate with the multiplicity of actors working on normative production, it is generated one of the basic values of postmodernity, according to Erik Jayme, which is pluralism. "In the language of Law pluralism means to have available alternatives, options, possibilities" (JAYME, 1999, p. 29). Taking into consideration that Law is not able, momentarily, to regulate the subject of nanotechnology, aspect which is also present in the Consumer Protection Code, new possibilities are drawn, from the legal pluralism, to achieve the dialogue among the sources of $\mathrm{Law}^{25}$.

A título de sugestão, mas para ser tratado melhor em outra pesquisa, a seguinte forma estrutural seria mais razoável se tivesse no seu bojo:

1. Dos princípios que norteiam o desenvolvimento nanotecnológico;

2. Da política nacional a ser adotada pelas empresas;

3. Da política nacional no tratamento de resíduos nanotecnológicos;

4. Da política nacional a ser adotada pelas universidades no âmbito da pesquisa e do patenteamento;

5. Da política nacional a ser adotada pelo Poder Público;

6. Da política nacional a ser adotada pela sociedade civil - organizada ou não.

Ponto fulcral é que a população não tem como exercer a participação social sem o conhecimento que se adquire através da educação, comprometida com a informação transparente e eficaz, de tal forma, que emancipe o cidadão para o fim colimado com a proposta: exercício da livre escolha consciente.

\footnotetext{
${ }^{24}$ TIMM, Luciano Benetti. Ainda sobre a função social do direito contratual no Código Civil brasileiro: justiça distributiva versus eficiência econômica. In TIMM, Luciano Benetti. Direito \& Economia. (Org.). 2. ed. ver. e atual. Porto Alegre: Livraria do Advogado, 2008, p. 82.

25 BOTHA, Anthon. Future Thinking and Managemente of Technology. IAMOT, 2015. Disponível em: http://www.iamot2015.com/documents/FutureThinkingAndMOT-IAMOT2015.pdfAcesso em 31 jul. 2015.
} 
Demais disso, qualquer proposta legislativa de iniciativa brasileira deverá ser pautada em harmonia com as disposições internacionais das quais o Brasil assinou ser parte, a exemplo do europeu NanoReg ${ }^{26}, 2014$, cujo projeto pretende tratar da regulação internacional e criar um banco de dados, em consórcio com todos os países, acerca das informações técnicas envolvendo nano e que devem ser alimentadas e podem ser consultadas por todos os aderentes. Portanto, qualquer legislação nacional que pretenda travar a batalha da regulação, não poderá escapar das obrigações assumidas internacionalmente, a fim de promover maior segurança jurídica interna e externa, já que, outros países estão mais avançados cientificamente a respeito do assunto. Engelmann concorda com essa conclusão: That is, the constructed response should still be aligned with the international standards on Human Rights and meet legal decisions already produced by International Courts of Human Rights, being regional or global27.

Inclusive, por ocasião da adesão ao projeto, Flávio Plentez, coordenador geral de Nanotecnologia da Secretaria de Desenvolvimento Tecnológico e Inovação (SETEC) do Ministério de Ciência, Tecnologia e Inovação, em entrevista dada ao Portal Brasil, em 27/08/2014 ${ }^{28}$, ressaltou que o projeto europeu visa dar suporte técnico e científico a todas as questões de regulação, portanto poderia ser objeto de consulta pelo país nos projetos que pretende discutir:

É um projeto que vai alimentar e dar subsídios confiáveis a todos os órgãos e agências, sejam eles internacionais ou nacionais, afetos a cada país, para a tomada de decisões e regulamentações, elaboração de leis e para todas as outras questões relacionadas à regulamentação e regulação da nanotecnologia. [...].

Entretanto, considerando a hipótese legislativa, importa fincar as estruturas do sistema dialógico entre todos os envolvidos na cadeia do ciclo de vida dos nanoprodutos, sem exclusão da participação democrática da sociedade civil, tanto da esfera pública quanto privada, por que, senão, corre-se o risco de perpetuar a eterna luta pelo poder, concentração de riquezas e pelo choque de egos, cujo resultado negativo pertence à população, tal como afirmado Alberto Cupani em seu artigo intitulado "a realidade complexa da tecnologia":

Como foi apontado inúmeras vezes, a ciência moderna e a tecnologia dela resultante ou por ela possibilidade são manifestação e instrumento de 'vontade de poder', contrária a toda resignação ou temor ante a realidade, próprios de outras épocas e civilizações. [...]. Em todo caso, o controle parece ser o valor central do/no mundo

\footnotetext{
${ }^{26}$ Segundo se pode ler na página principal do NanoReg: "O potencial inovador e econômico dos nanomateriais engenheirados está ameaçado pela compreensão limitada dos aspectos de segurança ao longo das cadeias de valor. Esforços substanciais deram insights toxicidade e a exposição para nanomateriais. No entanto, o conhecimento de hoje não é suficientemente abrangente para fins de regulação, a resposta a perguntas abertas é urgentemente necessária. A abordagem em circulação da NANoREG irá fornecer as respostas certas para a Sociedade, a Indústria e os Regulamentos nacionais e as autoridades Legislação”. Disponível em: < http://nanoreg.eu/> Acesso em 30 jul. 2015.

27 BOTHA, Anthon. Future Thinking and Managemente of Technology. IAMOT, 2015. Disponível em: http://www.iamot2015.com/documents/FutureThinkingAndMOT-IAMOT2015.pdfAcesso em 31 jul. 2015.

${ }^{28}$ Disponível em: <http://www.brasil.gov.br/ciencia-e-tecnologia/2014/08/comite-de-nanotecnologia-aprova-adesao-do-brasilao-nanoreg>. Acessado em 25 jul.2015.
} 
tecnológico, acompanhado de outros como a eficiência, a precisão, a previsibilidade e a vantagem (no caso das tecnologias industriais, comerciais, bélicas, políticas). [... $]^{29}$.

A propósito, em outro trabalho, Engelmann atribui a essa proposta dialógica, democrática e horizontalizada o nome de "governo por objetivos" e o define a partir da qualidade da comunicação entre as partes envolvidas no desenvolvimento da nanotecnologia: trabalhadores, consumidores, empresas, sindicatos, órgãos reguladores etc., a fim de humanizar a técnica e os seus possíveis efeitos maléficos antes que eles ocorram ${ }^{30}$.

Boaventura de Sousa Santos, no mesmo sentido de Engelmann, menciona que os atritos gerados pela comunicação entre os agentes envolvidos, de um lado, pela força da hegemonia econômica de alguns; de outro, pela força contra hegemônica exercida pelos interlocutores, é capaz de gerar o equilíbrio no mercado, senão vejamos:

Não deixa de ser surpreendente que os traços principais da governação neo-liberal se encontrem também presentes na matriz da governação contra-hegemónica que subjaz o Forum Social Mundial: a participação voluntária, a horizontalidade, a coordenação, a parceria, a auto-regulação etc. [...] $]^{31}$.

Nesse diapasão, na parte que toca aos agentes que desenvolvem e investem em inovação que a análise econômica do direito pode contribuir para a criação de um ponto de contato entre todos os agentes envolvidos no desenvolvimento, exploração e fruição dos benefícios trazidos pelas nanotecnologias, pois, coloca as variantes sociais - pessoas e o meio ambiente - e os riscos - entendidos como infortúnios previsíveis ou incertos, como fatores numéricos no cálculo de exploração econômica.

E não é só isso. Esse cálculo deve ser sob a égide da orientação racional das decisões corporativas eficientes e responsável; e não somente eivada de boas intenções, mas, eminentemente, lucrativas. Os investimentos em nanotecnologia devem ter valor agregado. Para isso, é necessário o desprendimento da dogmática jurídica e da classificação das fontes de direito de tradição romano-germânica, por óbvio; pois as considerações jurídicas que se pretende partem da metodologia econômica que analisa os fatos sociais e os comportamentos econômicos para auxiliar, ao final, na própria construção de diretrizes e ou regras jurídicas de caráter econômico, cujo fim é agregar valor à sociedade, efetivando os ditames constitucionais horizontalizados.

Na aplicação da Teoria da Análise Econômica do Direito, entendida essa, pelo presente ensaio, como análise econômica do direito natural das pessoas que suplanta, em muito, regras morais e normas positivadas, a conta matemática da administração empresarial deve inserir como fator determinante para o cálculo de investimento em inovação, o percentual de risco ou incerteza, mensurável ou não, para o destinatário final da operação. Assim, se o risco de infortúnios for superior ao, reconhecidamente, tolerável, o investimento deverá ser

29 Disponível em: <http://www.ihuonline.unisinos.br/index.php?option=com_content\&view=article\&id=5794\&secao=459> Acesso em 30 jul. 2015.

${ }^{30}$ ENGELMANN, Wilson. O Direito frente aos desafios trazidos pelas nanotecnologias. In STRECK, Lenio Luiz; ROCHA, Leonel Severo e ENGELMANN, Wilson. Constituição, Sistemas Sociais e Hermenêutica. ANUÁRIO de Pós-Graduação em Direito da UNISINOS. Mestrado e Doutorado. Porto Alegre: Livraria do Advogado, 2013, n. 10.

${ }^{31}$ SANTOS, Boaventura Sousa. A gramática do tempo: para uma nova cultura política. 3. ed. São Paulo: Cortez, 2010, p. 414 , v. 4. vol.09, no. 01, Rio de Janeiro, 2016.pp. 460-484 
interrompido ou postergado, ou, então, os investimentos deverão ser redirecionados para a pesquisa da mitigação dos riscos ou das incertezas.

Daí, é que a Teoria da Análise Econômica do Direito prescreve valor econômico à norma, pois, é através dela que a matemática do cálculo administrativo será feito sendo esta uma variante no cômputo final da atividade econômica. Rachel Sztajn explica que a ciência produzida pela Law and Economics (Nova Economia Institucional) vem da "percepção da importância de recorrer a alguma espécie de avaliação ou análise econômica na formulação de normas jurídicas visando a torná-las cada vez mais eficientes"32.

Vale transcrever:

Por que, então, não associar eficácia à eficiência na produção de normas jurídicas? Eficácia como aptidão para produzir efeitos e eficiência como aptidão para garantir o melhor resultado com o mínimo de erros ou perdas, obter ou visar ao melhor rendimento, alcançar a função prevista de maneira amais produtiva. Elas deveriam ser metas de qualquer sistema jurídico. A perda de recursos/esforços representa custo social, indesejável sob qualquer perspectiva que se empregue para avaliar os efeitos ${ }^{33}$.

Tal teoria foi preconizada por Ronald Coase (Escola de Chicago; Nobel de Economia; 1991) e, rejeita a premissa neoclássica também criticada por Marx em seus estudos, que é pautada por escolhas hiperracionais para alcançar a maximização de lucros e gerar capital excedente (mais valia). Coase acolhe dois fatores determinantes na modificação da teoria: a economia dos custos das transações e a limitação da racionalidade lucrativa, tornando a atividade mais eficiente pela interdependência entre os envolvidos, por causa da inclusão das pessoas, das organizações (reguladoras das relações sociais; empresas) e das instituições (conjunto de regras escritas e não escritas) na matemática econômica, ou seja, o valor agregado.

Richard A. Posner, faz a diferença necessária para a compreensão do que seja a diferença entre riqueza social versusutilidade econômica, com o seguinte texto:

Desde Adam Smith, o termo 'valor', em economia, geralmente, se refere a valor de troca; medido ou ao menos mensurável no âmbito de um mercado, seja este explíito ou implícito. Do conceito de valor, deriva o de riqueza da sociedade como soma de todos os bens e serviços no interior desta, calculados pelo valor que possuem ${ }^{34}$.

O diagrama representa o universo do ideal científico pretendido com a teoria.

\footnotetext{
${ }^{32}$ SZTAJN, Rachel. Law and Economics. In SZTAJN, Rachel e ZYLBERSZTAJN, Décio (Org). 20 Tiragem. Direito \& Economia. Rio de Janeiro: Campus e Elsevier, 2005, p. 75.

${ }^{33}$ SZTAJN, Rachel. Law and Economics. In SZTAJN, Rachel e ZYLBERSZTAJN, Décio (Org). 20 Tiragem. Direito \& Economia. Rio de Janeiro: Campus e Elsevier, 2005, p. 81.

${ }^{34}$ POSNER, Richard A. A economia da justiça. São Paulo: Martins Fontes, 2010, p. 72. _vol.09, n. 01, Rio de Janeiro, 2016. pp. 460-484 

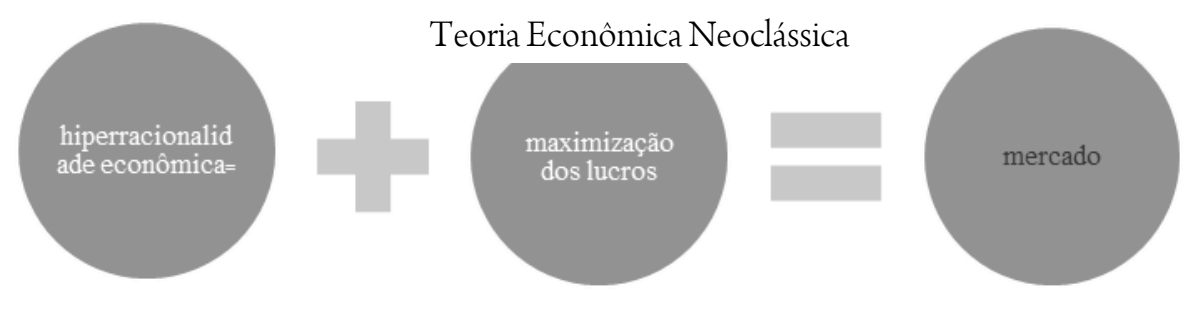

Teoria da Nova Economia Institucional
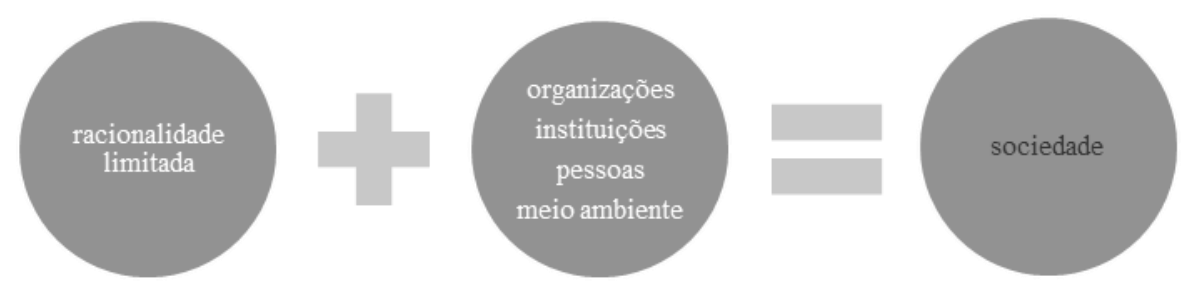

O Brasil vem resistindo à assimilação da teoria em nosso sistema, muito embora tenha sido aplicada, com bastante ousadia, em recente julgado judicial. A proposta, entretanto, é a de que deva ser absorvida e aplicada, também, às corporações, grandes, médias e pequenas, fora da esfera judicial, a fim de promover o bem-estar social e melhor aproveitamento com o desenvolvimento.

Vale transcrever trecho da ementa, cuja relatoria pertenceu ao Ministro Luís Felipe Salomão, pois, tratase de um avanço significativo para a justiça social, pois, reenquadra os agentes econômicos no seu papel institucionalizado, atribuindo-lhes sua função social, tal como preconizado pelo legislador constitucional (art. 170):

1. A análise econômica da função social do contrato, realizada a partir da doutrina da análise econômica do direito, permite reconhecer o papel institucional e social que o direito contratual pode oferecer ao mercado, qual seja, a segurança e previsibilidade nas operações econômicas e sociais capazes de proteger as expectativas dos agentes econômicos, por meio de instituições mais sólidas, que reforcem, ao contrário de minar, a estrutura do mercado. $[. . .]^{35}$.

Assim, lançando um olhar sobre a compreensão do que seja a economia dos custos das transações a partir da teoria de Posner é possível compreender, no caso das nanotecnologias, que os riscos futuros que possam concretizar-se e causar prejuízos de toda ordem às pessoas e ao meio ambiente, devem ser monetária e socialmente tão altos que sejam hábeis a ensejar a desmotivação do lucro pelo risco, senão vejamos:

O conceito básico da ECT é que existem problemas futuros potenciais nos contratos, problemas esses que são antecipados pelos agentes que desenham os arranjos institucionais no presente. Os agentes podem descumprir promessas, motivados pelo oportunismo e pela possibilidade de apropriação de valor de investimentos de ativos específicos. $\mathrm{Na}$

\footnotetext{
${ }^{35}$ Recurso Especial de no 1.163.283/RS (2009/0206657-6).
} 
impossibilidade de desenhar contratos completos (decorrência da racionalidade limitada), as lacunas são inevitáveis. Os agentes, potencialmente oportunistas, sentir-se-ão estimulados a romper ou adimplir os contratos, sendo justificável a existência de um corpo legal, formal, de normas, que se soma às regras informais, para disciplinar o preenchimento das lacunas ${ }^{36}$.

Já o aspecto abordado por Posner quanto à limitação da racionalidade corporativa está intimamente ligada com a satisfação das pessoas e não com a maximização dos lucros, tendo em vista, a capacidade limitada do ser humano em prever todos os eventos futuros e assim, a incompletude dos contratos para exaurirem todas as situações de riscos, portanto, as decisões são tomadas a partir da prevenção dos riscos e não deixadas ao consumidor final a escolha pelo perigo ou não:

A principal lição decorrente da substituição do pressuposto de hiperracionalidade pela racionalidade limitada é a substituição do objetivo de maximização pelo de satisfação, ou seja, encontrar um curso de ação que seja 'bom o suficiente', e a lição decorrente de atribuir a fragilidade emocional aos atores humanos (Simon, op. Cit., 1985) descrevendo o comportamento como predominantemente benigno. [... ${ }^{37}$.

Ivo Gico Junior esclarece que o envolvimento entre Direito e Economia é necessário, pois, discute e busca o valor econômico e agregado da norma jurídica. Isto significa dizer que qualquer recorte epistemológico que subtraia parte do todo e se investigue isoladamente, corre-se o risco das premissas racionais e os resultados matemáticos serem falsos, ou, no mínimo, socialmente imprestáveis:

O direito é, de uma perspectiva mais objetiva, a arte de regular o comportamento humano. A economia, por sua vez, é a ciência que estuda como o ser humano toma as decisões e se comporta em um mundo de recursos escassos e suas consequências. A Análise Econômica do Direito (AED), portanto, é o campo do conhecimento humano que tem por objetivo empregar os variados ferramentais teóricos e empíricos econômicos e das ciências afins para expandir a compreensão e o alcance do direito e aperfeiçoar o desenvolvimento, a aplicação e a avaliação das normas jurídicas, principalmente com relação à suas consequências ${ }^{38}$.

Para se chegar a dar efetividade à Análise Econômica do Direito pelas empresas, dois fatores são imprescindíveis na seara do comprometimento com o exercício da atividade econômica que agregue valor à sociedade: a ética e a gestão corporativa. Ambas ferramentas devem ser o mote dos comportamentos corporativos, dentro e fora das dependências empresariais. A ética ocupa espaço preponderante na precaução do risco e a governança corporativa atua como normatizador do valor agregado na exploração da atividade nanotecnológica, ou seja, a prevenção mediante adoção de políticas - boas práticas democráticas. Esses dois fatores auxiliam a operação econômica na maximização da riqueza e, institucionaliza os agentes econômicos.

Em se tratando de nanotecnologia, a NanoÉtica é o ramo da ciência que converge estudos sobre nanotecnologia, biotecnologia, informação e conhecimento, sendo aplicada a partir da realidade concreta e como um guia prático, cujo enfoque parte de conceitos filosóficos sobre a evolução técnica e a evolução ética e pretende

\footnotetext{
36 ZYLBERSZTAJN, Décio e SZTAJN, Rachel. Análise Econômica do Direito e das Organizações. In SZTAJN, Rachel e ZYLBERSZTAJN, Décio (Org). 20 Tiragem. Direito \& Economia. Rio de Janeiro: Campus e Elsevier, 2005, p. 08.

${ }^{37}$ WILLIAMSON, Oliver. Por que Direito, Economia e Organizações? In SZTAJN, Rachel e ZYLBERSZTAJN, Décio (Org). 2 Tiragem. Direito \& Economia. Rio de Janeiro: Campus e Elsevier, 2005, p. 21.

${ }^{38}$ TIMM, Luciano Benetti (Org.). Direito e Economia no Brasil. São Paulo: Atlas, 2012, p. 01.
} vol.09, nº. 01, Rio de Janeiro, 2016.pp. 460-484 
chamar a atenção à responsabilidade na tomada de decisões, a partir de quatro pilares valorativos: o não abuso da neutralidade, o pluralismo democrático, a versatilidade e a flexibilidade e, sobretudo, o cuidado no desenvolvimento.

A propósito, Engelmann acrescenta às ideias aqui debatidas que "a gestão do risco engloba a atuação gerencial da boa-fé, como aquele agir sem a intenção de causar prejuízo ou dano"39. Contudo, há de se observar que a ética reclamada nesta pesquisa não é a ética das boas intenções, mas, sim, a ética da responsabilidade. Bem como, os critérios de governança corporativa que se reclama nesta pesquisa, não são aqueles atrelados, somente, aos interesses dos stakeholders ${ }^{40}$ e shareholders ${ }^{41}$, mas, sim, a inclusão de diálogos com a sociedade civil, organizada ou não, e com o Poder Público, na construção dos Códigos Deontológicos corporativos em toda a cadeia de vida de uma nanopartícula e de uma política democrática e horizontalizada para que seja efetiva ${ }^{42}$.

Humberto Galimberti leciona que a ética se divorciou da técnica, pois, o exercício da ética tornou-se empecilho para a razão técnica. A ética se preocupa com a moral e com as boas políticas sociais, cujo objetivo é a coletividade; já a técnica se preocupa com os resultados de sua atividade, ignorando as consequências de seus inventos, pois, ao longo da história, “[...] a antiga convicção que atribuía à ética a tarefa de escolher os fins, e à técnica o encontro dos meios para a sua realização, é ultrapassada no dia em que o fazer técnico assumiu como fins aqueles que resultam de suas operações"33.

E mais. A ética está no campo do agir, pois a prática desse verbo prescinde da sabedoria, da responsabilidade e do respeito à natureza; já no campo do fazer está a técnica, que se desprende da ética, para dominar a natureza, imitando seus processos de produção e aprimorando sua autonomia em relação a ela, tornando-se excessivamente impessoal. E, assim, o homem se separou do seu criador para dominar toda a criação e perdeu a capacidade de agir, enquanto práxis e passou a buscar resultados possíveis pela tecnologia - a techne.

Entende o autor que só a ética da responsabilidade pode auxiliar o agir humano, mediante o exercício de uma consciência própria das consequências da tomada de decisão acerca de uma implementação tecnológica.

Se só se pode falar de 'responsabilidade' na presença de uma consciência da própria ação e das suas consequências, lá onde o saber individual e coletivo é inadequado à ordem de grandeza de competência técnica que confere poder ao nosso agir, dificilmente as palavras

\footnotetext{
${ }^{39}$ ENGELMANN, Wilson. O diálogo entre as fontes do direito e a gestão do risco empresarial gerado pelas nanotecnologias: construindo as bases à juridicização do risco. In STRECK, Lenio Luiz; ROCHA, Leonel Severo e ENGELMANN, Wilson. Constituição, Sistemas Sociais e Hermenêutica. ANUÁRIO do Programa de Pós-Graduação em Direito da UNISINOS. Mestrado e Doutorado. Porto Alegre: Livraria do Advogado, 2012, p. 392, n. 9.

${ }^{40}$ Stakeholders é uma nomenclatura estrangeira para identificar os grupos de interesses que são externos à atividade das empresas, mas são atingidos, direta ou indiretamente, por ela.

${ }^{41}$ Shareholders é uma nomenclatura estrangeira para identificar os grupos de interesses que são internos à atividade das empresas e são atingidos, diretamente, por ela.

${ }^{42}$ Neste sentido, consultar: DALTON-BROWN, Sally. Nanotechnology and Ethical Governance in the European Union and China: towards a global approach for Science and technology. New York: Springer, 2015.

${ }^{43}$ GALIMBERTI, Humberto. Psiche e Techne. O homem na idade da técnica. São Paulo: Paulus, 2006, p. 519.
} vol.09, nº. 01, Rio de Janeiro, 2016.pp. 460-484 
pronunciadas por uma ética da responsabilidade’ podem não digo ser eficazes, mas assumir algum significado no âmbito do fazer técnico. [... $]^{44}$.

Assim, entende-se que a ética da responsabilidade empresarial à luz dos ensinamentos de Robert Henry Scrour deve ser caracterizada pela análise das situações concretas e se antecipar às repercussões advindas das decisões tomadas. E mais, entende que a ética da responsabilidade tem como tomada de decisão: a) a indução, e não a dedução; b) a reflexão sobre os resultados futuros; c) o conhecimento das circunstâncias; d) a análise dos riscos; e) o cálculo de custo-benefício; f) a presunção de fins valiosos e universais ${ }^{45}$.

De outro lado, as políticas corporativas a serem adotadas, identificadas e desenhadas nos códigos deontológicos devem ser de tal envergadura que sejam construídas a partir da realização do bem comum (ética da responsabilidade) e não como limitação aos males a serem evitados (ética da convicção). Demais disso, em tempos globalizados, as empresas, sobretudo, as transnacionais, assumem papel importante na construção social e são parte ativa integrante na construção dos sistemas nacionais, pois dele fazem parte quando constroem através dos códigos deontológicos em conformidade com os organismos internacionais a que estão sujeitas, na observação de Gunther Teubner ${ }^{46}$.

Robert Slater, da Carleton University, ao tratar do assunto princípios de boa governança quanto a situações de risco pelo desconhecimento das implicações nanotecnológicas futuras (known unknown), dispôs, em seu discurso, primeiramente que é importante estabelecer que o risco é diferente da incerteza; sendo que o risco parte das possibilidades matemáticas de ocorrerem e incertezas não; pois não há, sequer, qualquer probabilidade mensurável, problema este enfrentado pelo estado das artes do atual desenvolvimento nanotecnológico. E conclui que, uma boa governança para a nanotecnologia prescinde de dez princípios ${ }^{47}$, a saber:

\footnotetext{
${ }^{44}$ Idem, p. 525.

${ }^{45}$ SCROUR, Robert Henry. Ética empresarial. O ciclo virtuoso dos negócios. 3. ed. ver. e atual. Rio de Janeiro: Campus, 2008, p. 127.

${ }^{46}$ TEUBNER, Gunther. Autoconstitucionalização de corporações transnacionais? Sobre a conexão entre os códigos de conduta corporativos (Corporate Codes of Conduct) privados e estatais. In SCHWARTZ, Germano. (Org.). Juridicização das esferas sociais e fragmentação do direito na sociedade contemporânea. Porto Alegre: Livraria do Advogado, 2012, p. 109.

${ }^{47}$ SLATER, Robert. The regulation ok known unknowns: toward good regulatory governance principles. In Regulatory Governance Principles - RGI. No 3. March 2009. Carleton University. School of Public Policy and Administration. Disponível em www.carleton.ca/sppa.
} 


\begin{tabular}{|c|c|}
\hline \multirow{10}{*}{$\begin{array}{c}\text { Good } \\
\text { Regulatory } \\
\text { Governance } \\
\text { Principles }\end{array}$} & $\begin{array}{l}\text { A entidade reguladora deve ter orçamento, instalações e pessoas competentes para tomada } \\
\text { de decisões que estejam baseadas em evidências. }\end{array}$ \\
\hline & $\begin{array}{l}\text { O processo regultório deve envolver todas as partes interessadas e ser sensível às } \\
\text { suas necessidades. }\end{array}$ \\
\hline & $\begin{array}{l}\text { A regulação deve ser clara quanto ao seu papel, seus objetivos e autoridade jurídica } \\
\text { e política, sobretudo, primar pela adoação de políticas ao invés de regulamentação. }\end{array}$ \\
\hline & $\begin{array}{l}\text { O agente regulador deve agir com responsabilidade e ser transparente quanto a } \\
\text { pretensão das normas, dos processos e das decisões. }\end{array}$ \\
\hline & $\begin{array}{l}\text { Os reguladores devem ser capazes de informar a todos envolvidos nas decisões acerca da } \\
\text { antecipação de eventuais crises, quando houver necessidade de adoção de medidas } \\
\text { burocráticas e políticas ("falar a verdade ao poder"). Os executivos devem ter a capacidade } \\
\text { de ouvir e compreender. }\end{array}$ \\
\hline & $\begin{array}{l}\text { O sistema de regulamentação deve ser em nível nacional e internacional, progressista e } \\
\text { antecipatório, sempre que possível. A gestão do conhecimento deve sertratado no estado da } \\
\text { arte em que se encontra. }\end{array}$ \\
\hline & $\begin{array}{l}\text { A abordagem sobre os riscos deve compor o objetivo e serem vistos como oportunidade para } \\
\text { superação completa (através da incorporação de uma perspectiva de sistemas e análise de } \\
\text { ciclo de vida, por exemplo). }\end{array}$ \\
\hline & $\begin{array}{l}\text { O sistema regulatório deve ser desempenho-orientado, eficiente e eficaz, e se esforçar para } \\
\text { a tomada de decisão oportuna e para implementação. Os tomadores de decisão devem se } \\
\text { esforçar para equalizar, proporcionalmente, benefícios e custos da regulação. }\end{array}$ \\
\hline & $\begin{array}{l}\text { Os padrões e os processos regulatórios devem ser razoavelmente consistentes e previsíveis. } \\
\text { A flexibilidade pode ser necessária quando envolver novas superficies de conhecimento } \\
\text { intensivo (outilier information). Nestes casos, os reguladores vão se esforçar para manter a } \\
\text { consistência na aplicação dos valores e do espírito das políticas adotadas. }\end{array}$ \\
\hline & $\begin{array}{l}\text { A cultura regulatória é baseada em um fundamento ético forte e consciente da importância do } \\
\text { conhecimento e juridicização no processo de regulamentação. A liderança promove a tomada } \\
\text { de decisão justa e competente e a manutenção das diversas capacidades necessárias } \\
\text { (incluindo conhecimentos científicos e técnicos, a alfabetização científica, capacidade } \\
\text { analítica, comunicação, valores partilhados, cooperação, abertura, previdência, perspectiva } \\
\text { internacional e outros elementos desejáveis para uma regulamentação corporativa). É } \\
\text { também um bom trabalho para equilibrar os riscos organizacionais e públicos. }\end{array}$ \\
\hline
\end{tabular}

Dos princípios norteados verifica-se que há três grupos de interesses que foram contemplados pelas diretrizes: os legitimados a ter voz ativa na elaboração da gestão (todos os interessados); os dirigentes, seus perfis e comportamento na gestão, sobretudo, dialógica (os agentes corporativos devem ter habilidades para gerenciamento de crises, de humanos, de política, administração, de transparência, de desenvolvimento técnico e científico); e, por fim, os critérios éticos que devem ser observados e aplicados de forma inegociável como uma boa cultura de regulação. Demais disso, também é possível contemplar que as diretrizes apontadas servem para nortear, tanto a regulação privada quanto orienta, claramente, os agentes públicos interessados em regulamentação, pois, demonstra, claramente, a pretensão em colaborar com a construção normativa das leis.

Nesse mesmo sentido, Nilson Lautenschleger Junior aponta para a importância da regulação como forma de sobrevivência econômica e, sobretudo, que "pode-se resumir o conceito de competição de forma bruta 
na afirmação de que os países que não adotarem regras adequadas de governança corporativa irão perder potencial parcela do mercado internacional ${ }^{m}$.

Assim, poderia, nesse exato momento, construir-se uma fórmula sugestiva:

$$
\mathrm{N} \& \mathrm{~N}=\mathrm{ECT}=\text { Etica }(\mathrm{GC}+\text { Prev }- \text { Risco })+\text { RLtda }=\text { Des e } \mathrm{Luc}^{49}
$$

Note-se que a ousadia da pretensão esbarra na limitação de suas variantes; talvez, outras externalidades que devam ser computadas na fórmula, a depender do caso concreto, todavia, todas elas deverão convergir para o resultado final que se pretende alcançar e não negociar: o homem!

\section{CONCLUSÕES}

Há muito, o homem tem buscado a técnica como solução para a sua alma. Para isso, abstraiu toda observação da natureza através de sua capacidade incomensurável de elaboração neurosensorial e, em decorrência dessa habilidade que o diferencia dos demais animais, passou a afastar-se da natureza e a projetar modelos de utilidade para satisfazer suas necessidades.

Nesse estado das artes humanas, a técnica solapou o homem e tomou a cena principal, escravizando esse ser que, tardiamente, reclama por reflexões críticas de si mesmo e de suas condutas, estando divididos entre retroceder e encontrar-se ou avançar e tresloucar-se com a sua própria dizimação.

A técnica da nano partícula é o retrato puro desse perdimento, diante da irracionalidade com que se desenvolve, se aplica e se assume riscos contra si mesmo, frente as incertezas científicas. Mas, como o Direito não tem condições de fazer-se valer nesse processo mediante legislação, isoladamente, por inúmeros fatores, eis que abstrato e longe do fato social, mister a interferência de outras ciências para tentar salvar o homem da avalanche do risco excessivo pelas inovações.

Se, inicialmente, a pesquisa se propôs a auxiliar na construção jurídica no que tange à regulação do tema desenvolvimento nanotecnológico, confirmou, ao final, que a desejada construção prescinde do diálogo entre Direito, Economia, pesquisadores, agentes internacionais e nacionais, sem exclusão do Estado - regulamentador e executivo -, sociedade civil - organizada ou não. Todos, em uma grande mesa de discussão de interesses para que a democracia e o desenvolvimento social e econômico sejam fortalecidos no Brasil, em cumprimento aos ditames constitucionais e internacionais assumidos. Só assim são possíveis o fortalecimento institucional e o almejado

\footnotetext{
${ }^{48}$ LAUTENSCHLEGER JUNIOR, Nelson. Os desafios propostos pela governança corporativa ao direito empresarial brasileiro. Ensaio de uma reflexão comparada. São Paulo: Malheiros, 2005, p. 146.

${ }^{49}$ Nanotecnologia e Nanociência $=$ Economia dos Custos da Transação = Ética (Governança Corporativa + Prevenção - Risco) + Racionalidade Limitada = desenvolvimento social e lucro. 
desenvolvimento sustentável com a mitigação ou compartilhamento consciente dos riscos advindos das nanotecnologias, de forma consciente por todos os atores envolvidos.

Verificou-se, também, que a hipótese inicial de aplicação da Análise Econômica do Direito é possível favorecer esse encontro e convergir os interesses, desde que, os agentes econômicos, bem como os envolvidos no investimento em inovação, possam repensar a maximização do lucro em favor da maximização de riquezas universais, mediante a prática da ética da responsabilidade e da elaboração corporativas de políticas de valor agregado ao homem e ao meio ambiente.

\title{
THE NANOTECHNOLOGY AND THE EXPLOITATION OF NATIONAL RICHES FROM THE CONTRIBUTION OF ECONOMIC ANALYSIS
}

\begin{abstract}
The our Federal Constitution, 1988, Article 170, provides that private companies make up the economic order of the country and, therefore, are responsible, alongside the neo-liberal state that's in Brazil, the national wealth creation and social and economic advancement of population. It is also constitutional corollary that economic development hampered by social, legal and economic contours that guarantee to Brazilian citizens their dignity. When it comes to nanotechnology exploration it is are able to observed that these dictates are not being met by the State allows, and the companies that put in circulation, goods of all kinds manufactured from nanotechnology, without the necessary social security in the face of numerous economic advantages. It appears, therefore, that there is a mathematical operation cost, whose factors are in disharmony with the claim of constitutional legislator. Why adopts this government and corporate policy in Brazil? What would be the perfect calculation to meet the desired balance the constitutional legislator? These questions will be investigate that does not have the power to exhaust the subject. Probably, at the end, will be noted that the economic analysis of law of the Chicago School has already been recognized by the our Judicial Courts and can help us in the solution to construction the social safety versus profit, precisely to go through the challenge of building a just and egalitarian society, collimated political ends in the Constitutional Charter.
\end{abstract}

Keywords: Socio-economic Development. Nanotechnology. Risks. Economic Analysis of Law. Balance.

\section{REFERÊNCIAS BIBLIOGRÁFICAS}

AGÊNCIA BRASILEIRA DE DESENVOLVIMENTO INDUSTRIAL. Agência Brasileira de Desenvolvimento Industrial Panorama nanotecnologia / Agência Brasileira de Desenvolvimento Industrial. - Brasília: ABDI, 2010. 180 p. (Série Cadernos da Indústria ABDI XIX).

CARVALHO, Edmir de. (Org.). Perspectivas da Globalização e das suas contradições no Brasil e na América Latina. LCTE. São Paulo:2010.

GALIMBERTI, Umberto. Psiche e Techne. O homem na idade da técnica. Paulus. São Paulo: 2006. 
GIDDENS, Anthony. Mundo em descontrole. O que a globalização está fazendo de nós. $6^{\circ}$ ed. Record. Rio de Janeiro: 2007.

LAUTENSCHLEGER JUNIOR, Nelson. Os desafios propostos pela governança corporativa ao direito empresarial brasileiro. Ensaio de uma reflexão comparada. Malheiros. São Paulo: 2005.

MATIAS, João Luís Nogueira. (coord.). Neoconstitucionalismo e Direitos Fundamentais. Atlas. São Paulo: 2009.

PINHO, Diva Benevides e VASCONCELOS, Marco Antônio Sandoval de. (Org.). Manual de Economia $4^{\circ}$ ed. Saraiva. São Paulo: 2003.

POSNER, Richard A. A economia da justiça. Martins Fontes. São Paulo: 2010.

SANTOS, Boaventura Sousa. A gramática do tempo: para uma nova cultura política. Vol. 4. $3^{\circ}$ ed. Cortez. São Paulo: 2010.

SCHWARTZ, Germano. (Org.). Juridicização das esferas sociais e fragmentação do direito na sociedade contemporânea. Livraria do Advogado. Porto Alegre: 2012.

SCROUR, Robert Henry. Ética empresarial. O ciclo virtuoso dos negócios. $3^{\circ}$ ed. Revista e Atualizada. Campus. Rio de Janeiro: 2008.

SLATER, Robert. The regulation ok known unknowns: toward good regulatory governance principles. In Regulatory Governance Principles - RGI. No 3. March 2009. Carleton University. School of Public Policy and Administration.

STRECK, Lenio Luiz; ROCHA, Leonel Severo e ENGELMANN, Wilson. Constituição, Sistemas Sociais e Hermenêutica ANUÁRIO do Programa de Pós-Graduação em Direito da UNISINOS. Mestrado e Doutorado n. 9. Livraria do Advogado. Porto Alegre: 2012.

Constituição, Sistemas Sociais e Hermenêutica. ANUÁRIO de Pós-Graduação em Direito da UNISINOS. Mestrado e Doutorado n. 10. Livraria do Advogado. Porto Alegre: 2013.

TIMM, Luciano Benetti. Direito \& Economia. (Org.). 2o ed. Revista e atualizada. Livraria do Advogado. Porto Alegre: 2008.

Direito e Economia no Brasil. Atlas. São Paulo: 2012.

ULRICH, Beck. Sociedade de risco - rumo a uma outra modernidade. Tradução de Sebastião Nascimento. $2^{\circ}$ Ed. Editora 34. São Paulo: 2011.

WEBER, Max. A ética protestante e o espírito do capitalismo. Companhia das Letras. São Paulo: 2004.

ZYLBERSTAJN, Décio e SZTAJN, Rachel. Direito e Economia - Análise Econômica do Direito e das Organizações. (Org.). $2^{\circ}$ Tiragem. Campus e Elsevier. Rio de Janeiro: 2005.

\section{REFERÊNCIAS EXTRAÍDAS DA INTERNET:}

http://www.abdi.com.br/Estudo/Panorama\%20de\%20Nanotecnologia.pdf, acessado em 30 de julho de 2015. 
https://qualidadeonline.wordpress.com/category/nanotecnologia/, acessado em 30 de julho de 2015.

http://wwwl.folha.uol.com.br/mercado/2015/05/1632954-cientistas-abrem-pequenas-empresas-investindoem-nanotecnologia.shtml, acessado em 30 de julho de 2015.

http://www.abdi.com.br/Estudo/Relat\%C3\%B3rio\%20Nano-Riscos_FINALreduzido.pdf, acessado em 30 de julho de 2015.

https://www.google.com.br/search?q=nanotoxicologia+e+dados\&sa=N\&es_sm=93\&biw=1022\&bih=619\&tb $\mathrm{m}=$ isch\&tbo=u\&source=univ\&ei=EjsfVfSEI8WmNuXBgeAO\&ved=0CCUQ $s A Q 4 C g \#$ imgdii=_\&imgrc=6XF WR1SQCrLgFM\%253A\%3Be1fBNcSBKU27M\%3Bhttp\%253A\%252F\%252Fwww.elsevier.pt\%252Fimatges\% 252F323\%252F323v31n02\%252Fgrande\%252F323v31n0290259647fig2.jpg\%3Bhttp\%253A\%252F\%252Fww. elsevier.pt\%252Fpt\%252Frevistas\%252Frevistaportuguesa-saude-publica323\%252Fartigo\%252Fnanomateriaismanufaturados-novos-desafios-saude-publica90259647\%3B700\%3B488; acessado em 30 de julho de 2015.

http://www.unochapeco.edu.br/quimica/noticias/lancado-banco-de-dados-com-informacoes-de-riscos-dananotecnologia-para-o-consumidor; acessado em 30 de julho de 2015.

http://www.mct.gov.br/upd_blob/0004/4795.pdf, acessado em 30 de julho de 2015.

http://www.brasil.gov.br/ciencia-e-tecnologia/2014/08/comite-de-nanotecnologia-aprova-adesao-do-brasil-aonanoreg, acessado em 30 de julho de 2015.

http://www.huonline.unisinos.br/index.php?option=com_content\&view=article\&id=5794\&secao=459, acessado em 30 de julho de 2015.

http://www.ihu.unisinos.br/images/stories/cadernos/ideias/218cadernosihuideias.pdf, acessado em 30 de julho de 2015.

Trabalho enviado em 28 de setembro de 2015.

Aceito em 06 de dezembro de 2015. 